\title{
Correlations and path analysis among agronomic and technological traits of upland cotton
}

\author{
F.J.C. Farias ${ }^{1}$, L.P. Carvalho ${ }^{1}$, J.L. Silva Filho ${ }^{1}$ and P.E. Teodoro ${ }^{2}$ \\ ${ }^{1}$ Centro Nacional de Pesquisa de Algodão, Embrapa Algodão, Campina Grande, \\ PB, Brasil \\ ${ }^{2}$ Departamento de Fitotecnia, Universidade Estadual do Mato Grosso do Sul, \\ Aquidauana, MS, Brasil \\ Corresponding author: P.E. Teodoro \\ E-mail: eduteodoro@hotmail.com
}

Genet. Mol. Res. 15 (3): gmr.15038239

Received December 9, 2015

Accepted January 18, 2016

Published August 12, 2016

DOI http://dx.doi.org/10.4238/gmr.15038239

Copyright (C) 2016 The Authors. This is an open-access article distributed under the terms of the Creative Commons Attribution ShareAlike (CC BY-SA) 4.0 License

\begin{abstract}
To date, path analysis has been used with the aim of breeding different cultures. However, for cotton, there have been few studies using this analysis, and all of these have used fiber productivity as the primary dependent variable. Therefore, the aim of the present study was to identify agronomic and technological properties that can be used as criteria for direct and indirect phenotypes in selecting cotton genotypes with better fibers. We evaluated 16 upland cotton genotypes in eight trials conducted during the harvest 2008/2009 in the State of Mato Grosso, using a randomized block design with four replicates. The evaluated traits were: plant height, average boll weight, percentage of fiber, cotton seed yield, fiber length, uniformity of fiber, short fiber index, fiber strength, elongation, maturity of the fibers, micronaire, reflectance, and the degree of yellowing. Phenotypic correlations between the traits and cotton fiber yield (main dependent variable)
\end{abstract}


were unfolded in direct and indirect effects through path analysis. Fiber strength, uniformity of fiber, and reflectance were found to influence fiber length, and therefore, these traits are recommended for both direct and indirect selection of cotton genotypes.

Key words: Gossypium hirsutum L.r. latifolium Hutch; Fiber length; Genetic breeding

\section{INTRODUCTION}

Upland cotton (Gossypium hirsutum L.r. latifolium Hutch.) is used in the production of one of the most important textile fibers of the world (Farias et al., 2016). Because it offers various useful products of great relevance for the Brazilian and world economies, it is among the plants that are the most exploited and economically important in Brazil (Carvalho et al., 2015a). Globally, Brazil is already the world's fifth largest cotton seed producer, with 4.4 million tons produced in the harvest 2013/14. The production is concentrated to the CentroOeste region with $66 \%$ of the total amount, and the State of Mato Grosso is the largest domestic producer (Conab, 2015).

Changes in spinning technology, competition with synthetic fibers, and the globalization of cotton production and textile products increases the demand for higher fiber quality (Smith et al., 2008). To become competitive in the global market, currently dominated by Australia, whose fiber is of excellent quality, industries require greater strength for spinning and bundling, reduced short fiber content, and greater uniformity in length and mature fibers. All these traits are desirable for increasing processing speed in the textile industry (Smith et al., 2008).

One of the major traits that still needs to be improved is the fiber length. To this end, an understanding of the correlations between agronomic and technological traits is critical in breeding programs. This is because selection based on one trait may result in changes in other important agronomic traits as well. This occurs because these correlations do not determine the relative importance of direct and indirect effects of the traits that comprise grain yield (Lynch and Walsh, 1998).

Path analysis, as proposed by Wright (1921), allows for a better understanding of different trait associations, through the unfolded of correlation coefficients in direct and indirect effects on the trait of interest (Corrar et al., 2007). Estimates of these effects are obtained by regression equations in which the variables are first standardized. However, for cotton crop, few studies have used this method for breeding purposes and the few studies that have been done to this end, all used fiber yield as the primary dependent variable (Tyagi et al., 1998; Iqbal et al., 2003; Hoogerheide et al., 2007).

Thus, the current study aimed to identify which agronomic and technological traits can be used as direct and indirect selection criteria for cotton genotypes with higher fiber contents.

\section{MATERIAL AND METHODS}

Eight trials with upland cotton genotypes were conducted during the harvest 2008/2009 in the State of Mato Grosso in the following municipalities: Campo Verde, Campo Novo dos Parecis, Lucas do Rio Verde, Nova Ubiratã, Pedra Preta, Primavera do Leste (two trials), and Sapezal. The experimental design adopted consisted of a randomized complete blocks with

Genetics and Molecular Research 15 (3): gmr.15038239 
16 treatments (BRS ARAÇA, BRS BURITI, BRS 286, FMT 701, FM 993, FM 910, DELTA OPAL, IPR JATAI, LD CV 05, LD CV 02, BRS CEDRO, NUOPAL, CNPA MT 05 1245, CNPA MT 04 2080, CNPA MT 04 2088, and BRS 293) with four replicated each. The culture practices were the ones commonly used for growing cotton, including the use of herbicides for weed control and pest control, according to the integrated management of pests recommended for crop in the region.

The experimental unit consisted of four $5.0 \mathrm{~m}$ long rows, spaced at $0.90 \mathrm{~m}$ at a density of nine plants $/ \mathrm{m}$. The agronomic traits evaluated were: plant height $(\mathrm{PH}, \mathrm{cm})$, average boll weight (ABW, g), concept (CON), percentage of fibers (PF, \%), cotton seed yield (YS, kg/ha), and cotton fiber yield (YF, $\mathrm{kg} / \mathrm{ha}$ ). Twenty bolls from each experimental unit were evaluated for the following technological fiber traits: fiber length (FL, mm), uniformity of fiber (UNIF, $\%$ ), short fiber index (SFI, \%), fiber strength (FS, gf/tex), elongation (EL, \%), micronaire (MIC, mg/inches), reflectance (REF, \%), degree of yellowing (+b), spinning (SPI), and maturity of fibers (MAT, \%), using the high volume instrument from the Laboratory of Fibers of the Embrapa Algodão.

To verify the genetic variability among genotypes, a joint analysis of variance for each trait was carried out. This was done after detecting that the relationship between the largest and smallest residual mean square of the individual analyses of variance did not exceed the ratio 7:1 (Pimentel-Gomes, 2009). Subsequently, the among-trait phenotypic correlations were estimated. These were then unfolded in the path analysis, in direct and indirect effects, considering the following equation 1 :

$$
\mathrm{Y}=\mathrm{p}_{1} \mathrm{X}_{1}+\mathrm{p}_{2} \mathrm{X}_{2}+\ldots+\mathrm{p}_{\mathrm{n}} \mathrm{X}_{\mathrm{n}}+\mathrm{p}_{\varepsilon} \mathrm{u} \quad \text { (Equation 1) }
$$

where in $\mathrm{Y}$ is the principal dependent variable and $\mathrm{YF} ; \mathrm{X}_{1}, \mathrm{X}_{2}, \ldots, \mathrm{X}_{\mathrm{n}}$ are the independent explanatory variables; and $\mathrm{p}_{1}, \mathrm{p}_{2}, \ldots, \mathrm{p}_{\mathrm{n}}$ are the path analysis coefficients. The coefficient of determination $\left(\mathrm{R}^{2}\right)$ was calculated by the equation 2 :

$$
\mathrm{R}^{2}=\mathrm{p}_{1 \mathrm{y}}^{2}+\mathrm{p}_{2 \mathrm{y}}^{2}+\ldots 2 \mathrm{p}_{2 \mathrm{y}} \mathrm{p}_{2 \mathrm{n}} \mathrm{r}_{2 \mathrm{n}}
$$

The degree of multicollinearity of the $\mathrm{X}^{\prime} \mathrm{X}$ matrix was established based on its number of conditions (NC), which is the ratio between the largest and the smallest matrix eigenvalue (Montgomery and Peck, 2001). If $\mathrm{NC}<100$, the multicollinearity is weak and does not constitute a problem for the analysis. If $100 \leq \mathrm{NC} \leq 1000$, multicollinearity is considered moderate to strong, and if $\mathrm{NC}>1000$, the degree of multicollinearity is determined as severe. All statistical analyses were performed using the GENES software (Cruz, 2013).

\section{RESULTS AND DISCUSSION}

Significant differences $(\mathrm{P} \leq 0.05)$ were estimated by F-tests among cotton genotypes for all traits evaluated, allowing us to make inferences about the existence of genetic variability among genotypes (Table 1). The results obtained are similar to those obtained in other studies

Genetics and Molecular Research 15 (3): gmr.15038239 
of cotton crop (Freitas et al., 2007; Silva et al., 2011; Martins et al., 2012; Araújo et al., 2013; Jerônimo et al., 2014; Carvalho et al., 2015a,b).

Table 1. Summary of analysis of variance for plant height $(\mathrm{PH}, \mathrm{cm})$, average boll weight $(\mathrm{ABW}, \mathrm{g})$, concept $(\mathrm{CON})$, percentage of fibers (PF, \%), seed cotton yield (YS, $\mathrm{kg} / \mathrm{ha})$, cotton fiber yield (YF, $\mathrm{kg} / \mathrm{ha})$, fiber length (FL, mm), uniformity of fiber (UNIF, \%), short fiber index (SFI, \%), fiber strength, (FS, gf/tex), elongation (EL, $\%$ ), micronaire (MIC, $\mathrm{mg}$ / inches), reflectance (REF, \%), degree of yellowing (+b), spinning (SPI), and maturity of fibers (MAT, \%), evaluated in 16 cotton genotypes in eight environments in the State of Mato Grosso.

\begin{tabular}{l|c|c|c|c|c|c|c|c|c}
\hline Sources of variation & d.f. & PH & ABM & CON & PF & YS & YF & FL & UNIF \\
\hline Blocks/Environments & 24 & 267.03 & 0.17 & 0.21 & 1.78 & $1,569,116.36$ & $251,397.79$ & 0.66 & 0.70 \\
\hline Genotypes (G) & 15 & $1389.30^{*}$ & $2.46^{*}$ & $2.46^{*}$ & $52.71^{*}$ & $2,247,856.24^{*}$ & $699,658.49^{*}$ & $6.80^{*}$ & $4.08^{*}$ \\
\hline Environments (E) & 7 & $4870.05^{*}$ & $8.25^{*}$ & $3.16^{*}$ & $76.16^{*}$ & $76,415,198.24^{*}$ & $15,116,900.99^{*}$ & $14.26^{*}$ & $31.59^{*}$ \\
\hline G x E & 59 & $251.80^{*}$ & $0.19^{\text {ns }}$ & $0.12^{*}$ & $1.18^{\text {ns }}$ & $659,283.76^{*}$ & $125,611.74^{*}$ & $0.78^{*}$ & $1.10^{\text {ns }}$ \\
\hline Residual & 190 & 169.72 & 0.15 & 0.06 & 0.72 & $346,994.25$ & $65,633.24$ & 0.55 & 1.28 \\
\hline CV (\%) & - & 10.98 & 6.27 & 6.37 & 2.00 & 12.58 & 12.82 & 2.42 & 1.33 \\
\hline Mean & - & $118.68 \mathrm{~cm}$ & $6.10 \mathrm{~g}$ & 3.69 & $42.59^{\circ}$ & $4683.95 \mathrm{~kg} / \mathrm{ha}$ & $1999.25 \mathrm{~kg} / \mathrm{ha}$ & $30.82 \mathrm{~mm}$ & $85.35 \%$ \\
\hline Sources of variation & d.f. & SFI & FS & EL & MIC & REF & $+\mathrm{b}$ & SPO & MAT \\
\hline Blocks/Environments & 24 & 0.35 & 2.06 & 0.36 & 0.05 & 2.85 & 0.20 & 47.78 & 1.07 \\
\hline Genotypes (G) & 15 & $1.11^{*}$ & $13.16^{*}$ & $6.26^{*}$ & $0.78^{*}$ & $16.21^{*}$ & $1.73^{*}$ & $328.89^{*}$ & $8.89^{*}$ \\
\hline Environments (E) & 7 & $33.64^{*}$ & $98.64^{*}$ & $23.38^{*}$ & $5.38^{*}$ & $165.84^{*}$ & $2.92^{*}$ & $4100.78^{*}$ & $33.90^{*}$ \\
\hline G x E & 59 & $0.46^{\text {ns }}$ & $3.27^{*}$ & $0.48^{*}$ & $0.06^{\mathrm{ns}}$ & $2.94^{*}$ & $0.28^{*}$ & $79.53^{\text {ns }}$ & $1.00^{*}$ \\
\hline Residual & 190 & 0.40 & 2.75 & 0.30 & 0.06 & 2.02 & 0.17 & 83.03 & 0.61 \\
\hline CV (\%) & - & 11.16 & 5.38 & 7.80 & 5.30 & 1.85 & 5.75 & 5.94 & 0.91 \\
\hline Mean & - & 5.67 & $30.83 \mathrm{gf} / \mathrm{tex}$ & 7.00 & $4.52 \mu \mathrm{g} /$ inches & $76.65 \%$ & 7.16 & 153.38 & $85.96 \%$ \\
\hline
\end{tabular}

ns, *Not significant and significant according to an F-test at the 0.05 probability level, respectively; $\mathrm{CV}=$ coefficient of variation; d.f. $=$ degrees of freedom .

PH correlated positively $(\mathrm{P} \leq 0.05)$ with $\mathrm{PF}, \mathrm{YS}$, and YF (Table 2). This indicates that the selection of larger sized genotypes may result in improvement in productive traits. CON correlated negatively $(\mathrm{P} \leq 0.05)$ with $\mathrm{ABW}$ and UNIF and positively with SFI. There were also positive correlations $(\mathrm{P} \leq 0.05)$ between $\mathrm{PF} \times \mathrm{YS}$ and $\mathrm{PF} \times \mathrm{YF}$, indicating that $\mathrm{PF}$ may be used for direct selection on cotton genotypes with high cotton fiber yield. These results directly reflect on the high magnitude correlation $(\mathrm{P} \leq 0.05)$ found between $\mathrm{YS} \times \mathrm{YF}$. The negative correlations $(\mathrm{P}$ $\leq 0.05$ ) obtained between SFI $x$ UNIF and $+b \times$ REF were expected because of the antagonism between these traits. The SPI was positively correlated $(\mathrm{P} \leq 0.05)$ with UNIF, FS, and REF. In turn, MAT correlated positively $(\mathrm{P} \leq 0.05)$ with $\mathrm{YS}, \mathrm{YF}, \mathrm{FS}, \mathrm{MIC}$, and REF, which indicates that this trait can be used for direct selection for genotypes with good technological properties.

Table 2. Estimates of phenotypic correlations between plant height (PH), average boll weight (ABW), concept (CON), percentage of fibers (PF), seed cotton yield (YS), cotton fiber yield (YF), fiber length (FL), uniformity of fiber (UNIF), short fiber index (SFI), fiber strength (FS), elongation (EL), micronaire (MIC), reflectance (REF), degree of yellowing (+b), spinning (SPI), and maturity of fibers (MAT), evaluated in 16 cotton genotypes in eight environments in the State of Mato Grosso.

\begin{tabular}{|c|c|c|c|c|c|c|c|c|c|c|c|c|c|c|c|}
\hline Trait & $\mathrm{ABW}$ & CONC & $\mathrm{PF}$ & YS & YF & $\mathrm{FL}$ & UNIF & SFI & FS & EL & MIC & REF & $+\mathrm{b}$ & SPI & MAT \\
\hline PH & 0.0186 & -0.0016 & $0.6261^{*}$ & $0.7346^{*}$ & $\begin{array}{l}0.7869^{*} \\
\end{array}$ & 0.2504 & -0.1853 & 0.1573 & 0.1318 & -0.1620 & 0.1945 & 0.0249 & 0.2083 & -0.2174 & 0.3591 \\
\hline $\mathrm{ABW}$ & & $-0.6588^{*}$ & -0.2668 & -0.1702 & -0.2349 & -0.3579 & 0.2688 & -0.4447 & -0.3515 & 0.3747 & 0.0824 & -0.4038 & 0.5301 & -0.2125 & -0.2211 \\
\hline CONC & & & 0.2394 & 0.3382 & 0.3419 & 0.0886 & $-0.6414^{*}$ & $0.6663^{*}$ & 0.0474 & 0.0068 & -0.0259 & 0.0093 & -0.1121 & -0.2712 & 0.0539 \\
\hline $\mathrm{PF}$ & & & & 0.4806 & $0.7673^{*}$ & -0.0087 & -0.1951 & 0.1669 & 0.2445 & -0.0209 & $0.4950^{*}$ & 0.2300 & -0.1152 & -0.2665 & 0.4147 \\
\hline YS & & & & & $0.9304^{*}$ & 0.3688 & -0.4607 & 0.4351 & 0.0696 & -0.2356 & 0.3256 & 0.1033 & 0.0675 & -0.3552 & $0.5284^{*}$ \\
\hline $\mathrm{YF}$ & & & & & & 0.2623 & -0.4302 & 0.3897 & 0.1541 & -0.1919 & 0.4573 & 0.1769 & -0.0086 & -0.3733 & $0.5718^{*}$ \\
\hline FL & & & & & & & -0.1365 & 0.2899 & 0.0924 & -0.2797 & -0.3632 & 0.2367 & -0.2053 & 0.3697 & 0.0477 \\
\hline UNIF & & & & & & & & -0.8416 & 0.1024 & 0.2466 & -0.0478 & 0.3159 & -0.2647 & $0.6035^{*}$ & -0.1739 \\
\hline SFI & & & & & & & & & 0.2304 & $-0.5091^{*}$ & 0.1107 & -0.0754 & 0.0948 & -0.2897 & 0.3957 \\
\hline FS & & & & & & & & & & -0.4545 & 0.4263 & 0.7371 & $-0.5461^{*}$ & $0.5424^{*}$ & $0.5947^{*}$ \\
\hline $\mathrm{EL}$ & & & & & & & & & & & -0.2383 & -0.3576 & 0.3305 & -0.0628 & $-0.6956^{*}$ \\
\hline MIC & & & & & & & & & & & & 0.3009 & -0.1841 & -0.3082 & $0.8187^{*}$ \\
\hline REF & & & & & & & & & & & & & $-0.8942^{*}$ & $0.6192^{*}$ & $0.4730^{*}$ \\
\hline$+b$ & & & & & & & & & & & & & & $-0.5364^{*}$ & -0.3311 \\
\hline SPI & & & & & & & & & & & & & & & -0.1207 \\
\hline
\end{tabular}

*Significant according to the Student $t$-test at the 0.05 probability level.

Genetics and Molecular Research 15 (3): gmr.15038239 
The main causes of phenotypic correlation between traits are pleiotropism, the property by which a gene may simultaneously affect more than one trait; and linkage disequilibrium, the non-random association between alleles of different loci (Mode and Robinson, 1959). Thus, although important, the phenotypic correlation coefficient can produce misconceptions about the relation between two traits, and need not be a true measure of cause and effect. The strength of the correlation coefficient between two traits may be the result of an effect that a third trait or group of traits has on the traits, not giving the exact relative importance of the direct and indirect effects of the factors being analyzed (Cruz et al., 2004).

For these reasons, we proceeded to do a path analysis, which investigates the cause and effect of the relationships. Teodoro et al. (2014) mentions that this analysis provides a detailed knowledge of the traits' influence, and justify the existence of positive and negative correlations of high and low magnitude among the studied traits. However, for obtaining direct and indirect effects of path analysis, it is necessary that the $\mathrm{X}^{\prime} \mathrm{X}$ matrix be well conditioned. In the presence of multicollinearity, the variances associated with the estimators of the path coefficients can become excessively high, making the analysis unreliable. In addition, the parameter estimates can assume absurd or nonsense values in relation to the studied biological phenomenon (Cruz et al., 2004). According to the NC criterion presented by Montgomery and Peck (2001), the estimate matrix of the phenotypic correlations obtained here showed weak multicollinearity $(\mathrm{NC}=81)$. Thus, in the absence of multicollinearity, we could include all traits evaluated in the path analysis (Table 3 ).

Table 3. Estimates of the direct and indirect effects of the plant height (PH), average boll weight (ABW), concept (CON), percentage of fibers (PF), seed cotton yield (YS), fiber length (FL), uniformity of fiber (UNIF), short fiber index (SFI), fiber strength (FS), elongation (EL), micronaire (MIC), reflectance (REF), degree of yellowing $(+b)$, spinning (SPI), and maturity of fibers (MAT) on cotton fiber yield (YF) evaluated in 16 cotton genotypes at eight environments in the State of Mato Grosso.

\begin{tabular}{|c|c|c|c|c|c|c|c|c|c|c|c|c|c|c|c|}
\hline Effect & $\mathrm{PH}$ & $\mathrm{ABW}$ & $\mathrm{CON}$ & $\mathrm{PF}$ & $\mathrm{YS}$ & FL & UNIF & SFI & $\mathrm{FS}$ & EL & MIC & REF & $+\mathrm{b}$ & SPI & MAT \\
\hline Direct through YF & -0.0708 & 0.1071 & 0.1328 & 0.5061 & 0.7348 & -0.0010 & -0.1084 & -0.1742 & -0.0502 & -0.0922 & -0.0275 & -0.1062 & \begin{tabular}{|l|}
-0.0017 \\
\end{tabular} & 0.1742 & \begin{tabular}{|l|l|}
0.1245 \\
\end{tabular} \\
\hline Indirect through PH & & -0.0013 & 0.0001 & -0.0443 & -0.0520 & -0.0177 & 0.0131 & -0.0111 & -0.0093 & 0.0115 & -0.0138 & -0.0018 & \begin{tabular}{|l|}
-0.0147 \\
\end{tabular} & \begin{tabular}{|l|}
0.0154 \\
\end{tabular} & -0.0254 \\
\hline Indirect through $\mathrm{ABW}$ & 0.0020 & & -0.0705 & -0.0286 & -0.0182 & -0.0383 & 0.0288 & -0.0476 & -0.0376 & $\begin{array}{l}0.0401 \\
\end{array}$ & 0.0088 & -0.0432 & \begin{tabular}{|l|}
0.0568 \\
\end{tabular} & -0.0228 & 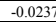 \\
\hline Indirect through CON & -0.0002 & -0.0875 & & 0.0318 & 0.0449 & 0.0118 & -0.0852 & 0.0885 & 0.0063 & 0.0009 & -0.0034 & 0.0012 & \begin{tabular}{|l|}
-0.0149 \\
\end{tabular} & \begin{tabular}{|l|}
-0.0360 \\
\end{tabular} & \begin{tabular}{|l|l|}
0.0072 \\
\end{tabular} \\
\hline Indirect through PF & 0.3169 & -0.1350 & 0.1212 & & 0.2432 & -0.0044 & -0.0987 & 0.0845 & 0.1237 & -0.0106 & 0.2505 & 0.1164 & -0.0583 & \begin{tabular}{|l|}
-0.1349 \\
\end{tabular} & \begin{tabular}{|l|l|}
0.2099 \\
\end{tabular} \\
\hline Indirect through YS & 0.5398 & -0.1251 & 0.2485 & 0.3532 & & 0.2710 & -0.3503 & 0.3197 & 0.0511 & -0.1731 & 0.2393 & 0.0759 & \begin{tabular}{|l|}
0.0496 \\
\end{tabular} & \begin{tabular}{|l|}
-0.2610 \\
\end{tabular} & \begin{tabular}{|l|l|}
0.3883 \\
\end{tabular} \\
\hline Indirect through $\mathrm{FL}$ & -0.0002 & 0.0003 & -0.0001 & 0.0000 & -0.0004 & - & 0.0001 & -0.0003 & -0.0001 & 0.0003 & 0.0004 & -0.0002 & \begin{tabular}{|l|}
0.0002 \\
\end{tabular} & \begin{tabular}{|l|}
-0.0004 \\
\end{tabular} & 0.0000 \\
\hline Indirect through UNIF & 0.0201 & -0.0291 & 0.0696 & 0.0212 & 0.0517 & 0.0148 & & 0.0913 & -0.0111 & -0.0267 & 0.0052 & -0.0343 & 0.0287 & \begin{tabular}{|l|}
-0.0654 \\
\end{tabular} & \begin{tabular}{|l|l|}
0.0189 \\
\end{tabular} \\
\hline Indirect through SFI & -0.0274 & 0.0775 & -0.1161 & -0.0291 & -0.0758 & -0.0505 & 0.1466 & & & 0.0887 & -0.0193 & 0.0131 & -0.0165 & 0.0505 & -0.0689 \\
\hline Indirect through FS & -0.0066 & 0.0176 & -0.0024 & -0.0123 & -0.0035 & -0.0046 & -0.0051 & -0.0116 & -0.0401 & & -0.0214 & -0.0370 & \begin{tabular}{|l|}
0.0274 \\
\end{tabular} & \begin{tabular}{|l|}
-0.0272 \\
\end{tabular} & -0.0299 \\
\hline Indirect through EL & 0.0149 & -0.0345 & -0.0006 & 0.0019 & 0.0217 & 0.0258 & -0.0227 & 0.0469 & 0.0419 & 0.0228 & & 0.0330 & -0.0305 & 0.0058 & \begin{tabular}{|l|l|}
0.0641 \\
\end{tabular} \\
\hline Indirect through MIC & -0.0053 & -0.0023 & 0.0007 & -0.0136 & -0.0089 & 0.0100 & 0.0013 & -0.0030 & -0.0117 & 0.0065 & 0.0220 & & 0.0051 & 0.0085 & -0.0225 \\
\hline $\begin{array}{l}\text { Indirect through REF } \\
\end{array}$ & $\begin{array}{l}-0.0026 \\
\end{array}$ & 0.0429 & -0.0010 & -0.0244 & -0.0110 & -0.0251 & -0.0335 & 0.0080 & -0.0783 & 0.0380 & -0.0319 & -0.0083 & & -0.0657 & -0.0502 \\
\hline Indirect through $+\mathrm{b}$ & $\begin{array}{l}-0.0003 \\
\end{array}$ & -0.0009 & 0.0002 & 0.0002 & -0.0001 & 0.0003 & 0.0004 & -0.0002 & 0.0009 & -0.0005 & 0.0003 & 0.0015 & \begin{tabular}{|l|}
0.0949 \\
\end{tabular} & & 0.0005 \\
\hline Indirect through SPI & -0.0379 & -0.0370 & -0.0472 & -0.0464 & -0.0619 & 0.0644 & 0.1051 & -0.0505 & 0.0945 & -0.0109 & -0.0537 & 0.1079 & -0.0934 & 0.0009 & \\
\hline Indirect through MAT & 0.0447 & -0.0275 & 0.0067 & 0.0516 & 0.0658 & 0.0059 & -0.0216 & 0.0493 & 0.0740 & -0.0866 & 0.1019 & 0.0589 & \begin{tabular}{|l|}
-0.0412 \\
\end{tabular} & \begin{tabular}{|l|}
-0.0150 \\
\end{tabular} & -0.0210 \\
\hline $\begin{array}{l}\text { Pearson correlation }(\mathrm{r}) \\
\end{array}$ & $0.7869^{*}$ & -0.2349 & 0.3419 & $0.7673^{*}$ & $0.9304^{*}$ & 0.2623 & -0.4302 & 0.3897 & 0.1541 & -0.1919 & 0.4573 & 0.1769 & -0.0086 & -0.3733 & $0.5718^{*}$ \\
\hline \multicolumn{16}{|c|}{ Coefficient of determination $=0.99$} \\
\hline
\end{tabular}

*Significant according to the Student $t$-test at the 0.05 probability level.

In breeding, it is important to identify, among the variables found to correlate strongly with the variable of interest, the ones that most directly and favorably affect selection, to obtain an efficient correlated response. We observed that the PF and YS traits were the most important, because they had the largest direct effects ( 0.5061 and 0.7348 , respectively) on the principal dependent variable (YF). This indicates the presence of cause and effect. Furthermore, these traits exerted indirect effects on each other and may therefore be used both for direct and indirect selection of cotton genotypes with high YF. In contrast to our results, Hoogerheide et

Genetics and Molecular Research 15 (3): gmr.15038239 
al. (2007), when working with a smaller database, found that FS and UNIF were the traits with the largest direct effects on YF.

Similarly, but to a lesser degree, MAT showed a positive direct effect on YF and positive indirect effects on PF and YS. In addition, MAT correlated positively with MIC and FS, indicating that this trait can be used for indirect selection of genotypes with greater fiber productivity and industrial quality. The $\mathrm{PH}$ showed a significantly positive correlation $(\mathrm{r}=$ 0.7869 ) with the main dependent variable, whereas a direct negative effect was observed on YF (-0.0708). This indicates that the correlation was caused by indirect effects, in particular the traits PF and YS. According to Coimbra et al. (2004), when observing strong negative direct effects, and strong positive indirect effects, the indirect selection cannot provide satisfactory gains. Thus, employment of simultaneous selection of traits is more appropriate (Cruz et al., 2004), confirming our hypothesis that the PF and YS traits explain most of the observed variability in YF.

The presence of negative indirect effects of PH, FL, UNIF, SFI, FS, EL, MIC, RF, and $+b$ illustrates the difficulty encountered when selecting only based on the behavior of the main variable (YF, in this case). Cruz et al. (2004) reported that, as yet, no suitable method is available to maximize the response to selection while considering only the main components of the main variable. Therefore, when the selection process is based only on YF, a loss of control may occur of the behavior of the technological cotton traits, which are a basic requirement for good cotton genotypes.

We obtained a high coefficient of determination (0.9998), which was higher than that obtained in other studies that have employed a path analysis in cotton (Iqbal et al., 2003; Hoogerheide et al., 2007). This suggests that the genetic effects related to the main dependent variable, YF, are very well explained by the model.

\section{Conflicts of interest}

The authors declare no conflict of interest.

\section{ACKNOWLEDGMENTS}

We thank Coordenação de Aperfeiçoamento de Pessoal de Nível Superior (CAPES) and Conselho Nacional de Desenvolvimento Científico e Tecnológico (CNPq) for financial support.

\section{REFERENCES}

Araújo WP, Pereira JR, Almeida ESAB, Araújo VL, et al. (2013). Componentes da fibra de cultivares de algodoeiro herbáceo sob lâminas de água. Rev. Edu. Agric. Sup. 28: 78-81.

Carvalho LP, Farias FJC and Rodrigues JIS (2015a). Selection for increased fiber length in cotton progenies from Acala and non-Acala types. Crop Sci. 55: 985-991. http://dx.doi.org/10.2135/cropsci2014.08.0547

Carvalho LP, Salgado CC, Farias FJC and Carneiro VQ (2015b). Estabilidade e adaptabilidade de genótipos de algodão de fibra colorida quanto aos caracteres de fibra. Cienc. Rural 45: 598-605. http://dx.doi.org/10.1590/0103$\underline{8478 \mathrm{cr} 2013023}$

Coimbra JLM, Guidolin AF, Almeida ML, Sangoi L, et al. (2004). Análise de trilha dos componentes do rendimento de grãos em genótipos de canola. Cienc. Rural 34: 1421-1428. http://dx.doi.org/10.1590/S0103-84782004000500015

Conab (2015). Companhia Nacional de Abastecimento. Acompanhamento de safra Brasileira: grãos, décimo segundo levantamento, Setembro/2015. http://www.conab.gov.br. Accessed November 30, 2015.

Genetics and Molecular Research 15 (3): gmr.15038239 
Corrar LJ, Paulo E and Dias Filho JM (2007). Análise multivariada. Atlas, Fipecafi.

Cruz CD (2013). GENES - a software package for analysis in experimental statistics and quantitative genetics. Acta Sci. Agron. 35: 271-276. http://dx.doi.org/10.4025/actasciagron.v35i3.21251

Cruz CD, Regazzi AJ, Carneiro AJ and Souza PC (2004). Modelos biométricos aplicados ao melhoramento genético. UFV, Viçosa.

Farias FJC, Carvalho LP, Silva Filho JL and Teodoro PE (2016). Biplot analysis of phenotypic stability in upland cotton genotypes in Mato Grosso. Genet. Mol. Res. 15: gmr.15038009.

Freitas RJ, Leandro WM and Carvalho MCS (2007). Efeito da adubação potássica via solo e foliar sobre a produção e a qualidade da fibra em algodoeiro (Gossypium hirsutum L.). Pesqui. Agropecu. Trop. 37: 106-112.

Hoogerheide ESS, Vencovsky R, Farias FJC, Freire EC, et al. (2007). Correlações e análise de trilha de caracteres tecnológicos e a produtividade de fibra de algodão. Pesquisa Agropecu. Bras. 42: 1401-1405. http://dx.doi. org/10.1590/S0100-204X2007001000005

Iqbal M, Chang MA, Iqbal MZ, Hassan M, et al. (2003). Correlation and path coefficient analysis of earliness and agronomic characters of upland cotton in Multan. Pakist. J. Agron. 2: 160-168. http://dx.doi.org/10.3923/ja.2003.160.168

Jerônimo JF, Almeida FAC, Silva ORRF, Brandão ZN, et al. (2014). Qualidade da semente e fibra de algodão na caracterização do descaroçador de 25 serras. Rev. Bras. Eng. Agric. Ambient. 18: 664-671. http://dx.doi.org/10.1590/ $\underline{\text { S1415-43662014000600015 }}$

Lynch M and Walsh B (1998). Genetics and Analysis of quantitative traits. Sinauer Associates, Sunderland.

Martins IS, Silva IM, Camargo JM, Melo LF, et al. (2012). Avaliação de características da fibra de genótipos de algodoeiro cultivados em sistemas ultra-adensado, adensado e convencional. Nucleus 9: 121-129. http://dx.doi. org/10.3738/1982.2278.653

Mode JC and Robinson HF (1959). Pleiotropism and the genetic variance and covariance. Biometrics 15: 518-537. http:// dx.doi.org/10.2307/2527650

Montgomery DC and Peck EA (2001). Introduction to linear regression analysis. John Wiley \& Sons, New York.

Pimentel-Gomes F (2009). Curso de Estatística Experimental. Fealq, São Paulo.

Silva RP, Ferreira IC and Cassia MT (2011). Perdas na colheita mecanizada de algodão. Scie. Agropec. 2: 7-12.

Smith CW, Hague S, Hequet E, Thaxton S, et al. (2008). Development of extra-long staple upland cotton. Crop Sci. 48: 1823-1831. http://dx.doi.org/10.2135/cropsci2008.01.0052

Teodoro PE, Silva CA, Junior., Corrêa CC, Ribeiro LP, et al. (2014). Path analysis and correlation of two genetic classes of maize (Zea mays L.). J. Agron. 13: 23-28. http://dx.doi.org/10.3923/ja.2014.23.28

Tyagi AP, Mor BR and Singh DP (1998). Path analysis in upland cotton (Gossypium hirsutum L.). Ind. J. Agric. Res. 22: $137-142$

Wright S (1921). Correlation and causation. J. Agric. Res. 20: 557-585.

Genetics and Molecular Research 15 (3): gmr.15038239 